\title{
School Policy in Supporting Indonesia Smart Program at Private Junior High School (SMP) of Santo Gabriel Sekadau
}

\author{
Neli $^{1)}$, M. Syukri ${ }^{2)}$, M. Chiar ${ }^{3)}$ \\ ${ }^{1)}$ Universitas Tanjungpura, Pontianak, Indonesia \\ E-mail: nelisekadau@gmail.com \\ ${ }^{2)}$ Universitas Tanjungpura, Pontianak, Indonesia \\ E-mail: syukri_fkip@yahoo.com \\ ${ }^{2)}$ Universitas Tanjungpura, Pontianak, Indonesia \\ E-mail: chiarfkip@gmail.com
}

\begin{abstract}
The purpose of this study is to obtain information about school policies in supporting PIP which is focused on the process of determining prospective PIP recipients, strategies implemented by the principal, procedures for implementing PIP policies, forms of PIP policies and constraints. With a qualitative approach, this research was compiled using interview data and document data. Data analysis uses data reduction, data presentation, and conclusion. This study found that the school policy in supporting PIP was in the form of (1) The process of determining prospective PIP recipients, namely the establishment of a PIP responsible committee equipped with assignments and referring to technical guidelines. Supporting documents for the determination of prospective PIP recipients in the form of new student admission forms, photocopies of COWs, photocopies of PIP cards, photocopies of KKS, and PKH; (2) The strategy carried out by the school principal in supporting PIP conducts socialization, proposing students who are eligible to receive PIP; and provide socialization / direction to students receiving PIP; (3) Procedures for implementing PIP policies are guided by technical guidelines; (4) In the form of the PIP policy in Santo Gabriel's private junior high school, the PIP funds were collected collectively by the principal, the PIP funds received were intended to pay for student re-registration, school fees, and books. The school submits a written report to the District Education Office regarding the realization and distribution of PIP funds; (5) Internal barriers in supporting PIP, namely: (a) Students do not understand PIP; (b) New student admission forms are incomplete; and (c) The committee has difficulty in determining eligible students to be submitted as candidates for PIP recipients. Whereas external barriers, namely student data sent centrally when disbursing some students are not all realized.
\end{abstract}

Keywords: School Policy; Indonesia Smart Program

\section{INTRODUCTION}

The Smart Indonesia Program (PIP) is a refinement of the Poor Student Assistance Program (BSM), which was originally a recipient of only students attending formal education institutions, now PIP recipients are students from poor / poor families consisting of school-age children (6-21 years) who go to formal and non-formal education institutions.

The program is expected to be able to build a superior generation and the younger generation people get a decent education. The PIP policy is a government program launched to overcome the problems that occur because there are still many cases found of students who experience difficult costs. PIP is needed by students from poor families because students from poor families are very vulnerable to dropping out. This is due to the economic condition of the families of students who are less supportive, so the students decide to stop school and choose to work.

Presidential Instruction No. 7 of 2014 mandates PIP to the Ministry of Education and Culture to prepare the Indonesia Smart Card (KIP) and channel PIP funds to students whose parents cannot afford to pay for their education. PIP through the Indonesia Smart Card is a continuation of the BSM program which includes students from elementary/MI, junior high school/MTs, senior high 
school/vocational/MA education levels, and students/residents studying at the Learning Activity Center (PKBM)/Course and training institutions to children school age such as street children, child labor, children in orphanages and children with disabilities from households/families with the lowest economic status nationally. The Presidential Instruction was strengthened by the Republic of Indonesia Minister of Education and Culture Regulation Number 19 of 2016 concerning PIP. PIP is defined as "cash assistance from the government given to students whose parents are not and/or unable to finance their education."

The main purpose of implementing the PIP is to help students who are less able to obtain proper education, prevent school dropouts, attract students to go back to school both at the elementary and secondary levels and to meet their school needs. This assistance is expected to be used by students in meeting school needs such as transportation costs for students going to school, school equipment costs, and pocket money. The existence of PIP is expected to no longer drop out of school for reasons of lack of costs.

Achieving the PIP objectives requires support from school residents regarding their respective roles, functions, and authorities in a coordinated manner to improve program effectiveness and efficiency in achieving goals. The role and function of the school is to disseminate information to all school members, update the data of prospective recipient students into the Dapodik application completely and correctly, propose those who are eligible to receive PIP but do not have KIP, submit information related to PIP to students receiving PIP funds, appeal supervision of the use of PIP funds to be in accordance with the provisions on the use of funds so that they do not drop out of school

Every school must be able to know what students really need. Both internal and environmental needs are expected to be able to make policies to achieve educational goals. The policy that needs attention is the continuity of education, especially for students who are economically challenged.

The existence of schools as formal institutions providing education plays a strategic role in the success of the National Education System. The principal as a manager and leader is responsible for translating and implementing the National Education policy set by the government. So, every policy must always relate to students for the welfare and educate the community.

It is necessary to pay close attention to the principal in making new policies. A new policy is the creation of new conditions from routines that allow getting resistance from school members. Therefore, it is necessary to involve the school community in creating and implementing new school policies so that there is a learning process, and commitment to the success of policies to support PIP. From the results of the preliminary study of school policies so that students who are eligible to receive PIP assistance from the principal ask the homeroom teacher to record and report to the principal the names of students from poor / poor families include aspects of having KIP, KKS holders, PKH holders, parents' income less than Rp1,000,000, - with the number of dependents of more than three people for the next school marking the feasibility status of students as potential recipients of PIP funds in the Dapodik application.

Suhardan et al. (2012: 69) state that education has an important role in increasing human resources, education influences the nation's economic growth. Education has an effect on productivity, also affects the fertility of the community. Education is a Human Resource to understand and be ready to deal with changes in life. In general, education is recognized as an investment in Human Resources, because it contributes greatly to the development of socio-economic life through increasing knowledge, skills, skills, attitudes and productivity of humans. Therefore education activities are difficult if they have to be measured by linear profit-seeking profits in the form of profit money as in other business worlds. The benefits of education are not always economic but also personal, social and cultural.

In supporting the PIP certain arrangements are needed so that the educational objectives expected by the stakeholders of the educational institution can be achieved. According to H.A.R. Tilaar \& Riant Nugroho (2008: 18) education policy is concerned with regulating life with fellow human beings, this shows the sociality aspect of human existence. One of the meanings of the education process is seeing education as one of the empowerment processes.

PIP is directed at assistance provided by the government not only for public schools but also private schools. One of the several private junior high schools in Sekadau is Santo Gabriel Middle School. Based on the results of the preliminary study at Santo Gabriel Middle School, information was obtained that SMP St. Gabriel obtained PIP, the number of students was large compared to the number of private school students in Sekadau, namely in the 2018/2019 school year there were 349 students with 12 classes. Most of these students come from villages which their parents work as farmers from poor / poor families. But in 2018 the number of students who received PIP services was 40 students, there were still many students of SMP Santo Gabriel who were classified as poor but did not get this PIP service.

The Sekadau Region of St. Gabriel's Middle School is quite well known and includes schools that excel, both in academic and non-academic fields. So that many parents are interested in sending their children to St. Gabriel Middle School. The wishes and expectations of parents of students are not supported by the economic conditions they have, the difficulties of personal costs that are always experienced by students as a result of the learning achievements of students from disadvantaged families disrupted.

Therefore researchers are interested in uncovering these problems by raising the title "School policy in supporting the Smart Indonesia Program in the private junior high school of Santo Gabriel Sekadau." This is related to the aim of providing access to education for children aged 6 to 21 years in order to reduce dropout rates through assistance with PIP provided by the government. It is hoped that with 
this PIP it will be effective, then the school dropout rates and education needs of the community can be fulfilled well.

\section{RESEARCH METHOD}

This study aims to describe the school policy in supporting the Indonesian program Smart at the Santo Gabriel Sekadau Middle School. The researcher described the school policy in supporting the Smart Indonesia Program clearly and deeply, in accordance with the events in the field without any attempt to manipulate. This research was conducted at the Santo Gariel Sekadau Middle School using a qualitative approach, in accordance with the goals and objectives to be achieved. The process of collecting data needed in this study uses interview methods and documents. Based on the method used, the data collection tool needed is in the form of interview guidelines, and guidelines for collecting documents. In this study, the data analysis technique used is qualitative analysis, meaning that the collected data, both primary and secondary, are classified, and then the data is obtained, and data processing is more commonly used as the phrase sentence interpretation of the processed data.

\section{RESULT AND DISCUSSION}

\section{A. Results}

School policy in supporting PIP in Santo Gabriel Sekadau private junior high school through the process of determining prospective PIP recipients, strategies implemented by school principals, procedures for implementing PIP policies, forms of PIP policies, and obstacles in supporting PIP. From the results of interviews supported by documents, the following is a description of the research findings:

1. The process of determining prospective PIP recipients

Based on the results of research data analysis on the process of determining prospective PIP recipients in Santo Gabriel Sekadau private junior high school some of the findings in this study were that the school had formed a PIP responsible committee, the committee was formed through a teacher council meeting and decided by deliberation. The committee determines the prospective PIP recipients by (1) Viewing and checking the new student admission form, especially looking at the data of students who have KIP, KKS, and PKH; (2) Propose eligible students as potential beneficiaries of PIP; (3) Updating data on students who have KIP, KKS, $\mathrm{PKH}$ and those proposed as candidates to receive PIP in the Dapodik application by the school Dapodik operator.

The parties involved in the determination of prospective PIP recipients are principals holding command and coordination functions in the organizational structure, the school operator functions to collect student data and PIP numbers, TU because they are in control of proper student documents submitted through data analysis. they fill in the admission of new students, and homerooms by submitting economically disadvantaged students as potential recipients of PIP to the operator through the principal.

2. The strategy implemented by the principal in supporting PIP

Based on the analysis of research data on the strategies implemented by the principals in supporting PIP, positive trends were found in schools that had socialized PIP to parents of students marked by an invitation letter to parents of students who planned to open a new teaching year and socialize PIP so that people old students understand PIP.

In proposing candidates for PIP recipients, the school asks KIP owner students to submit ownership of their cards to schools to be recorded as prospective PIP beneficiaries, then schools mark students' eligibility status and update student data in full. For students who do not have KIP, PIP beneficiaries can be proposed with a mechanism to select students who are eligible to receive PIP according to technical guidelines. In addition, the school provides socialization / direction to students who receive PIP funds regarding the utilization of funds. The main objective is to provide information to students who receive PIP funds so that they understand the use of PIP funds.

3. Procedure for implementing PIP policies at Santo Gabriel's private junior high school

From the results of data analysis on the procedures for implementing PIP policies in Santo Gabriel's private junior high school, a positive tendency was found, namely that schools had PIP technical guidelines. In the implementation of PIP, the school principal coordinates with the chairman of the foundation, the school committee, the teacher and the TU by holding a meeting. The committee responsible for PIP is referred to through meetings and conducted by deliberation, then the committee by the principal is given a letter of assignment.

Supervision is carried out by school principals, school committees, administrators of the foundation so that the implementation of the PIP is in accordance with the technical guidelines. So that students who get PIP use their funds for their educational needs. The aspects needed in supervision are: (1) Accuracy of the target of PIP fund recipients; (2) Number of recipient students who have disbursed and who have not disbursed PIP funds; (3) The accuracy of the amount of PIP funds received by students; (4) Conformity of utilization of PIP funds; and (5) achievement of PIP objectives.

4. Form the PIP policy at Santo Gabriel's private junior high school

Based on the results of data analysis on the form of PIP policy in Santo Gabriel's private junior high school, there was a positional tendency to collect PIP funds collectively by the headmaster so that students did not interfere with learning. Documents that must be 
submitted by the school principal when collecting student PIP funds are absolute accountability (SPTJM), a certificate from the principal, a photocopy of the principal's ID card, and a decree to appoint the principal.

PIP funds received by students are used to pay re-registration, pay tuition fees and book money if the PIP money is still available for other school purposes. Students who have stopped their PIP money cannot be transferred to other students, and the money cannot be disbursed. PIP fund disbursement through BRI Sekadau savings branch is simple, a simple savings book is not given to students but is kept in the school to make it easier if needed

The school has submitted a report on the realization of the PIP recipient to the Sekadau District Education Office in the form of the following documents: absolute accountability letter (SPTJM), certificate from the principal, photocopy of the principal's KTP, decree on appointment of headmaster, and list of PIP fund submissions to students supplemented by the signature of students who have received PIP funds.

5. Obstacles in supporting PIP

Based on the results of the analysis of research data on obstacles in supporting PIP, there are internal and external barriers. Internal obstacles in the form of students do not understand PIP, the data filled by students on the student admission form is incomplete. Whereas external barriers are students, who have KIP and students who are proposed as candidates who do not appear as a list of PIP recipients.

B. Discussion

The researcher discusses the results of this study directed at the study of findings seen from school policies in supporting PIP in the private junior high school of Santo Gabriel Sekadau.

1. The process of determining prospective PIP recipients

a. Establishment of a committee responsible for PIP

Based on the results of the interviews and the results of the documentation, there is a tendency for the PIP responsible committee to be formed through teacher council meetings in consultation at the beginning of the new school year. As a guideline for the committee in carrying out its duties, the principal gives a letter of assignment to the committee, and the school also has technical instructions for implementing PIP. This is also in accordance with the PIP technical guidelines regarding the role and function of the District / City Education Office number 4, namely: assigning PIP staff / data teams / management. The assignment letter given by the principal to the person in charge of PIP contains a description of his assignment, namely:

1) Conducting socialization and coordination regarding PIP to parents / guardians / students.

2) Record students are receiving PIP (holders of KIP / KPS.PKH / other proposed eligible students) in accordance with JUKNIS PIP.
3) Propose students as recipients of PIP in the proposed format in Dapodik school.

4) Search for and collect other supporting files for PIP recipient students.

5) Assisting the disbursement process, channeling monitoring and reporting on the realization of PIP funds in accordance with the PIP JUKNIS.

6) Coordinating and communicating between staff in supporting the implementation of PIP.

The job description given by the school principal is in line with the PIP JUKNIS about the role and function of the school / educational institution stating that:

1) Socialize and coordinate PIP to all school members

2) Schools must accept the registration of children aged (6 to 21 years) KIP owners who do not attend school as prospective students during the range of $\mathrm{PPDB}$ implementation and must be proposed and must be proposed as potential recipients of PIP funds / benefits

3) Identify students who have KIP and update the data of prospective recipient students into the Dapodik application completely and correctly

4) Identify, select, propose and determine students who do not have KIP in accordance with the priority targets and update the data of students as potential recipients of PIP funds in the Dapodik application completely and correctly

5) Submitting data on proposals for prospective PIP recipients, both KIP owner and / or KIP holders, to district / city offices or provincial education offices according to their authority

6) Delivering information to recipient students if the PIP funds are ready to be taken

7) Full responsibility for the truth of the data of the students proposed as potential recipients of PIP funds

8) Make a Certificate of Principal as a requirement for disbursement of funds by students at the bank / channeling institution and / or prepare other documents needed in accordance with the provisions

9) Carrying out PIP funds disbursement carried out collectively in accordance with the specified mechanism

10) Providing guidance to students receiving PIP funds regarding the provisions on the use of funds

11) Monitor the process of disbursing PIP funds at banks / channeling institutions

12) Record / report on students who have disbursed PIP funds to the district / city or provincial education office according to their authority.

b. The mechanism for determining prospective PIP recipients

The determination mechanism is a method / model carried out by the committee in determining 
prospective PIP recipients. Based on the results of interviews and documentation it can be concluded that to determine the prospective recipients of PIP is done by:

1) Viewing and checking the new student admission form, especially looking at the data of students who have KIP, KKS, and PKH.

2) Looking at the data on the new student admission form regarding the income of parents, the number of siblings of students and parents of students then recapitulating data on students who are worthy of being proposed as beneficiaries of PIP.

3) Updating data on students who have KIP, KKS, PKH and propose students who are eligible to receive PIP into the Dapodik application by the Dapodik school operator.

This is in line with the JUKNIS PIP which states that Proposal of PIP grant recipients is carried out through the following mechanism:

For formal school students (SD, SMP, SMA, and SMK) in the following ways:

1) KIP recipient students report ownership of their cards to their respective schools, to be recorded as potential recipients of funds / PIP benefits;

2) Schools mark the eligibility status of students as recipients of PIP funds / benefits by clicking or updating KIP student data into the Dapodik application correctly and completely, especially in the following data columns:

a) Student Name;

b) Place of birth

c) Date of birth;

d) Name of biological mother;

e) KIP Number. The data serves as a data proposal of recipient students from the school level to the technical directorate;

3) Schools mark Student eligibility status and enter KIP numbers into Dapodik applications as potential recipients of PIP funds / benefits; Based on the proposed data of PIP eligible students in the Dapodik application, the technical directorate will issue a Decree on the Determination of PIP Beneficiaries / Benefits for the purposes of PIP assistance. Students who do not have KIP can be proposed to get PIP funds / benefits by schools / SKB / PKBM / LKP or other non-formal educational institutions under the guidance of the Ministry of Education and Culture with the following mechanisms:

a) Schools / SKB / PKBM / LKP or other nonformal education units select and compile a list of students who are still active and do not have KIP as potential recipients of PIP funds / benefits with the following priorities:
(1) Students from PKH participant families:

(2) Students from families of KKS holders;

(3) Learners from poor / poor vulnerable families and / or with special considerations such as:

(a) Orphaned / orphaned / orphaned students from schools / social institutions / orphanages;

(b) Students affected by natural disasters;

(c) Physical disorders (inclusion students), disaster victims, from layoff parents, in conflict areas, from families of convicts, in LAPAS, having more than 3 brothers living in a house;

(d) Schools mark Student eligibility status as potential recipients of PIP funds / benefits in the Dapodik application referring to the results of school selection / verification.

c. Parties involved in determining prospective PIP recipients

The parties involved in the determination of candidates are those who participate in determining prospective PIP recipients by receiving a letter of assignment from the principal, the committee is given the trust of the implementation of PIP. The committee collects supporting data for students to make it easier to determine prospective PIP recipients.

Based on the results of interviews and documentation it can be concluded that the parties involved in the determination of prospective PIP recipients are: the principal holds the command and coordination functions in the organizational structure, the school operator functions to collect student data and PIP numbers, TU because they are in control of documents eligible students are submitted through analysis of the data they fill at the time of admission of new students, and homeroom by submitting economically disadvantaged students as potential recipients of PIP to the operator through the principal. this is in line with the JUKNIS PIP which states that: stakeholders can propose prospective PIP recipient students to the technical directorate after coordinating with the school for verification / validation purposes in accordance with the priority goals and requirements set.

d. Supporting documents for the determination of prospective PIP recipients

To determine the prospective PIP recipient the committee identifies student data in full which is feasible to be submitted as a beneficiary. As revealed by Sugiyono (2018: 329) explains that: documents are records of past events, document studies are a complement to the use of observation and interview 
methods. The committee collects data that has been sent by students to the TU at the time of admission of new students.

Based on the results of interviews and documentation it can be concluded that the supporting documents for the determination of prospective PIP recipients are in the form of new student admissions forms, photocopies of PIP cards, photocopies of KKS, and PKH. This is in accordance with JUKNIS PIP regarding the role and function of schools / educational institutions in points $\mathrm{c}$ and $\mathrm{d}$, namely:

c) Identify students who have KIP and update the data of prospective recipient students into the Dapodik application completely and correctly; d) Identify, select, propose and determine students who do not have KIP in accordance with the priority targets and update the data of students as potential recipients of PIP funds in the Dapodik application completely and correctly.

2. The Strategy Implemented by The Principal in Supporting PIP

a. Socialization to parents of students

Based on the results of the interviews and the results of documentation regarding the implementation of socialization to parents students showed a tendency that the school supports PIP by carrying out socialization to parents of students, there is an invitation letter for parents of students from the principal. The agenda that will be discussed during the socialization is stated in the invitation letter, namely: 1) Opening of the new school year; 2) Socialization of PIP. The socialization was held at the beginning of the school year so that parents understand more about PIP and if supporting data have not been equipped with parents, students can immediately complete it so that the committee can carry out its duties according to the JUKNIS and on target. Another trend is the student form equipped with supporting data, namely the large income of parents, the number of siblings, and for students who have KIP, $\mathrm{KKS}$, PKH equipped with a copy. It is also in accordance with JUKNIS PIP about the priority of target recipients number 1 and 2 points a to point e, namely:

1) Students who own KIP;

2) Students from poor / vulnerable families and / or with special considerations such as:

a) Students from the families of the Participants in the Hope Family Program (PKH);

b) Students from families of KKS holders;

c) Orphans / orphans / orphaned students from schools / social care institutions / orphanages;

d) Learners affected by natural disasters; e) Physical disorders (inclusion students), disaster victims, from layoff parents, in conflict areas, from families of convicts, in LAPAS, having more than 3 relatives living.

b. The mechanism for proposing prospective PIP recipients

Based on the results of interviews with Santo Gabriel's private junior high school about the mechanism for proposing PIP recipient candidates, there is a tendency to refer to the PIP JUKNIS. In proposing candidates for PIP recipients, the school asks KIP owner students to submit ownership of their cards to schools to be recorded as prospective PIP beneficiaries, then schools mark students eligibility status and update student data in full. Students who do not have KIP can be proposed as PIP beneficiaries with a mechanism to select students who are eligible to receive PIP. This is in accordance with JUKNIS PIP regarding the mechanism for proposing points a and $b$, namely:

a. KIP Ownership Students: 1) KIP recipient students report ownership of their cards to their respective schools, to be recorded as potential recipients of PIP funds / benefits; 2) Schools mark the eligibility status of students as recipients of PIP funds / benefits by clicking or updating KIP student data into the Dapodik application correctly and completely, especially in the following data columns: a) Student Name; b) Place of birth; c) Date of birth; d) Name of biological mother; e) KIP Number. 3) Schools mark Student eligibility status and enter KIP numbers into Dapodik applications as potential recipients of PIP funds / benefits. 4) Based on the proposed data of PIP eligible students in the Dapodik application, the technical directorate will issue a Decree on the Determination of PIP Beneficiaries / Benefits for the purposes of PIP assistance. b. Students Who Don't Have KIP: 1) Schools select and compile a list of students who are still active and do not have KIP as candidates for PIP funds / benefits with priority as follows: a) Students from PKH participant families; b) Students from families of KKS holders; c) Students from poor / vulnerable families and / or with special considerations such as 1. Orphaned / orphaned orphaned students from schools / social institutions / orphanages; 2. Students affected by natural disasters; 3. Physical disorders (inclusion students), disaster victims, from layoff parents, in conflict areas, from families of convicts, in LAPAS, having more than 3 brothers living in a house; 4 . The school marks the eligibility status of the students as potential recipients of PIP funds / benefits in the Dapodik application referring to the results of school selection / verification.

3. Socialization to PIP recipient students 
Based on the results of interviews with Santo Gabriel's private junior high school about the dissemination to PIP recipient students, the tendency of the school has provided socialization / direction to students receiving PIP funds regarding the utilization of funds. The main objective is to provide socialization to students who receive PIP funds so that they understand the use of PIP funds so that they can prevent the possibility of attending school due to financial difficulties, and reduce the cost of education for students. This is in accordance with JUKNIS PIP regarding the roles and functions of schools points a and $\mathrm{j}$, namely: a. Socialize and coordinate PIP to all school members ...; f. Provide guidance to PIP fund recipient students regarding the use of funds.

In conducting socialization, the school did not make a special invitation letter but through verbal notification to students regarding the time and place announced directly through the teachers who would teach in the classrooms.

3. Procedure for implementing PIP policy in Santo Gabriel's private junior high school

a. PIP Technical Guidelines

Based on the results of interviews and documentation about the procedures for implementing PIP policy in Santo Gabriel's private junior high school, there was a tendency that PIP technical guidelines were available. Guidelines for principals, committees, and teachers to implement PIP in schools are technical guidelines. The process of submitting prospective PIP recipients is guided by technical guidelines, materials for socialization for parents, and socialization for PIP recipient students taken from the PIP technical guidelines. The PIP technical guidelines include: a) PIP objectives; b) Value of funds; c) Priority of recipient targets; d) Recipient requirements; e) Implementation mechanism consisting of 1) Proposal mechanism; 2) Students proposed by stakeholders; 3) Distribution of funds / benefits of PIP; 4) Disbursement of PIP funds / benefits; 5) Virtual Account; 6) Obligations of PIP students; f) Roles and functions consisting of 1) District / city education office; 2) Schools / educational institutions; Channeling agency; g) Monitoring, evaluation, and reporting.

b. A form of coordination with educators and education staff

Based on the results of the interview and the results of the documentation on the form of coordination with educators and the educational attainment of the private junior high school of St. Gabriel, the tendency is limited to meetings through coordination meetings or information dissemination on certain information. To inform educators and education staff, it is conveyed through an invitation letter affixed to the information board. Another trend is that the school supports PIP by coordinating with educators and education personnel. Namely, there is a letter of meeting invitation for educators and education personnel from the school principal. The agenda that will be discussed during the socialization is stated in the invitation letter, namely: 1) Opening of the new school year; 2) Socialization of PIP. This coordination meeting was held in consultation at the beginning of the school year so that the educators and education staff would have more duties and responsibilities and understand PIP. this is in accordance with the opinion of Imam Gunawan and Noor Benty (2017: 417) which states that deliberations can be carried out internally, an agreement must be obtained so that the school can immediately implement all agreed decisions.

c. Supervision of PIP implementation

Every activity is expected to be monitored both at the beginning of the activity and at the end of the activity. This also applies to the implementation of PIP. Supervision is important to achieve accountability and transparency in the implementation of PIP; supervision aims to monitor and evaluate the progress of PIP implementation and achievements. This is in accordance with Law number 20 of 2003 concerning Article 66 of the National Education System in Maswardi M. Min (2016: 49), namely:

1) The government, regional government, education council, and school / madrasah committees supervise the implementation of education at all levels and types of education in accordance with their respective authorities. 2) Pangawasan, as referred to in paragraph (1), is carried out with the principle of transparency and public accountability. Based on the interviews, the supervision of the implementation of the PIP shows a tendency that supervision is carried out by school principals, school committees, administrators and district education offices. Supervision carried out by the committee and management of the foundation through oral reports from the principal during a coordination meeting. However the supervision carried out by the principal is done in two ways, namely through oral reports at the teacher council meeting and through writing that lists the names of PIP recipient students based on the technical directorate / Ministry of Education's decree and list of PIP funds handover to students whereas supervision is carried out by the district education office through writing consisting of absolute accountability (SPTJM), school head certificate, photocopy of the principal's KTP, photocopy of valid school principal appointment decree, and PIP fund handover list to students. This is in accordance with the opinion of Herujito in Imam Gunawan and Noor Benty (2017: 112) arguing that 
supervision can be done by 1) Direct monitoring of place (Personnel inspection); 2) Through oral reports (oral report); 3) Through writing (Written report); 4) Through special care (Control by exception.

d. Aspects of monitoring the implementation of PIP

Based on the results of interviews at Santo Gabriel private junior high school that the aspects that need supervision in PIP implementation are: 1) Accuracy of the target of PIP fund recipients, seeing and ensuring that students receive PIP funds from economically disadvantaged families; 2) The number of recipient students who have disbursed and who have not disbursed PIP funds, ensures that students who are still active in the school have no problems in disbursing their PIP funds; 3) The accuracy of the amount of PIP funds that students receive, ensuring the number of funds disbursed is in accordance with the amount received by PIP recipient students; 4) Conformity in the utilization of PIP funds, ensuring the utilization of funds received by students is used to meet the costs of education; 5) achievement of the PIP objectives, ensuring that obtaining PIP funds can complete their education to secondary education, preventing students from dropping out of school, attracting school-age children who are not in school so that they can get more educational services and reduce the personal costs of education. this is in line with the JUKNIS PIP regarding monitoring and evaluation number 3 aspects that need to be monitored in the form of:

a) Accuracy of target recipients of PIP funds at school / SKB / PKBM / LKP or other nonformal non-formal education units and / or district / city / province levels; b) Number of recipient students who have disbursed and who have not disbursed PIP funds; c) The accuracy of the amount of PIP funds received by recipient students at each level of education; d) Suitability of the use of PIP funds by students; e) Service of channeling institutions; f) Implementation of the roles and functions of each relevant agency in the implementation of the PIP; g) Achievement of PIP goals and objectives.

4. Form of PIP policy in Santo Gabriel's private junior high school

a. PIP fund collection mechanism

Based on the results of interviews and documentation at Santo Gabriel's private junior high school regarding the mechanism for taking PIP funds, there was a tendency for PIP funds to be collected collectively by the principal at the channeling bank, namely BRI branch Sekadau SIMPEL account (Student savings). This is in accordance with JUKNIS PIP regarding disbursement of funds / Benefits of PIP point $b$ regarding:
Collecting funds collectively by the school principal by bringing the following documents: 1) Power of Attorney from parents / guardians (for SD / Package A and SMP / Package B) or from students (for SMA / Package C and Vocational / Institution Courses) PIP recipient; 2) Absolute Accountability (SPTJM) (format attached); 3) Certificate of Principal / Chairperson of the Institution (format attached); 4) Photocopy of the Principal's KTP / Chair of the Institution and show the original; 5) Photocopy of Decree on Appointment of Principal / Chair of a definitive Institution that is still valid and shows the original; 6) Student passbooks taken collectively;

For the collective collection of the principal of Santo Gabriel's private junior high school from the channeling bank, only asking to bring 5 documents, namely: 1) Absolute accountability (SPTJM); 2) Certificate of headmaster; 3) Photocopy of the principal's ID card; 4) Photocopy of decree on the appointment of the principle that is still valid; 5) Student passbooks taken collectively documents that are not prepared, namely a power of attorney from parents / guardians or from PIP recipient students.

b. Allocation of utilization of PIP funds

Based on the results of interviews about the allocation of utilization of PIP funds in Santo Gabriel's private junior high school, the tendency of principals to always communicate with the teacher through meetings and to disseminate information to students is because they are a private school foundation school about using PIP funds received. Students are directed to pay re-registration, pay school fees, pay for books because that is in direct contact with the continuity of their education. There are those who pay off their school fees one year; some are half semester depending on the number of funds they receive because the PIP funds which they receive is varied. This is also found in the PIP JUKNIS about the purpose of PIP number 4, namely:

Easing the personal costs of education. The personal costs of such education include: a) Buying books and stationery; b) Buy school uniform / practice clothes and school supplies (shoes, bags or the like); c) Funding the transportation of students in schools; d) pocket money of students; e) Fees for additional courses / tutoring for formal education students; f) Additional practice costs and internship / work placement costs.

Another trend is that students listed in the list of decrees from the Technical / Ministry of Education and Culture Directorate are the same as the list of students who receive PIP funds, meaning that they are not transferred to other students. The names of students in the Decree are entitled to 
receive PIP funds. The number of funds stated in the decision letter for class IX amounted to Rp.375,000, - and for students of class VII and VIII amounted to Rp. 700,000. Students who attend the St. Gabriel private junior high school come from various districts in the eastern region of West Kalimantan, some from Sintang district, Sekadau district and Sanggau district. These students live in dormitories, and some live in boarding, allowing students to stop school. For example, a student in the name of Agnes Monika whose mother has died, his PIP funds cannot be withdrawn because the student has stopped. Lack of support, attention, and motivation from parents, is the main cause of these students choosing not to go to school anymore. After the PIP funds are disbursed the savings books are not given to students but are kept in the school to be safer if needed at any time is easy to obtain and does not require a long time. To withdraw PIP funds for students who already have a savings book the book must be taken, but if there are students who do not have a savings book, then the channeling bank will print it.

c. Report on realization of PIP recipients

Based on the results of the interview and the results of the documentation regarding the realization report of the PIP recipients, there was a tendency that the Santo Gabriel private junior high school had made a report on the realization of the receipt of the PIP funds to the Sekadau District Education Office. The realization report consists of a) Absolute accountability (SPTJM) from the principal. The contents of the SPTJM are about statements of absolute responsibility and responsibility of the principal; b) Certificate from the school principal explaining that the names of students on the list of recipients of the PIP scholarship are St. Gabriel's private junior high school students; c) Photocopy of KTP Principal; d) Decree on appointment of headmaster; e) List of submissions of PIP funds to students equipped with signatures of students who have received PIP funds. This is in accordance with JUKNIS PIP regarding reporting number 2 which states that schools / educational institutions make reports on PIP implementation.

d. Report on the use of PIP funds

Based on the results of interviews with Santo Gabriel's private junior high school regarding the report on the use of PIP funds, the school and students tend not to report the use of PIP funds. The principal did not ask students to report on the use of the funds they received but before the PIP funds were disbursed the principal had given instructions to the students so that the use of PIP funds to be received was prioritized to pay for re-registration and tuition in advance if more money could be available used to buy other school equipment such as stationery and can also be used to meet other needs which are certainly needed to support student learning.

5. Barriers to supporting PIP

Internal obstacles in the form of students do not understand PIP, the data filled by students on the student admission form is incomplete. Whereas the external obstacles are students, who are proposed as candidates who do not appear as a list of PIP recipients.

\section{CONCLUSION}

A. Conclusions

Based on the results of the research and discussion that have been presented relating to school policies in supporting PIP in the private junior high school of Santo Gabriel Sekadau, it can be concluded as follows:

1. The process of determining prospective PIP recipients has formed a committee responsible for PIP in accordance with mechanics. Supporting documents for the determination of prospective PIP recipients in the form of new student admission forms, photocopies of KK, photocopies of PIP cards, photocopies of KKS, and PKH.

2. The strategy implemented by the principal in supporting PIP, by disseminating information to parents of students at the beginning of the school year; and propose students who are eligible to receive PIP; and provide socialization / direction to PIP recipient students.

3. The procedure for implementing PIP policy in the private junior high school of St. Gabriel has had a PIP JUKNIS, Coordination between educators and education personnel through meetings. Supervision is carried out by school principals, school committees, administrators and district education offices.

4. Constraints in supporting PIP show a tendency in the form of internal (internal) obstacles and external (external) obstacles.

\section{B. Suggestions}

Based on the research findings, the problem of the research results and conclusions, then some suggestions that need to be conveyed regarding school policies in supporting PIP are as follows:

1. Determination of prospective PIP recipients requires complete supporting documents so that the accuracy of the PPDB committee is needed in accepting forms disguised by new students.

2. The strategy implemented by school principals in supporting PIP needs to be improved, especially in conducting socialization and coordination to parents of students and PIP recipient students to be more motivated and certainly no one to drop out of school.

3. The implementation of the PIP policy needs to be improved, especially on supervision, especially on monitoring the utilization of PIP funds received by students. 
4. The form of PIP policy needs to be improved, especially in the report on the use of PIP funds by students to schools, this is a form of supervision to educate them to feel responsible to themselves and others.

5. The obstacles found in supporting PIP need to be minimized related to the obstacles that arise by making targeted approaches and targeted socialization by the school so that the PIP is right on target.

\section{REFERENCES}

Abdul Wahab, Solihin. 2016. Analisis Kebijakan dari Formulasi ke penyusunan Model-model Implementasi Kebijakan Publik.. Jakarta: Bumi Aksara.

Abidin, Said Zainal. 2006. Kebijakan Publik. Jakarta: Suara Bebas.

Ali Saukah, Ah. Rofiuddin, Herawati Susilo, A. Mukhadis, Budi Eko Soetjipto, M.E. Winarno, Mulyadi Guntur Waseso, Margono, Aminarti S. Wahyuni. 2010. Pedoman Penulisan Karya Ilmiah. Malang: Universitas Negeri Malang.

Ali, Alam, Wantu. 2012. Studi Analisa Kebijakan. Bandung: Refika Aditama.

Dadang suhardan, Riduan, Enas. 2012. Ekonomi dan Pembiayaan Pendidikan. Bandung: Alfabeta.

Deddy Mulyadi. 2015. Studi Kebijakan Publik dan Pelayanan Publik: Konsep dan Aplikasi Proses Kebijakan Publik Berbasis Analisis Bukti Untuk Pelayanan Publik.. Bandun:. Alfabeta.

Dunn, William N. 2003. Pengantar Analisis Kebijakan Publik. Jogyakarta: Gajah Mada University Press.

Dunn, William N. 2007. Public Policy Analysis: Person.

Edi Suharto. 2015. Analisis Kebijakan Publik: Panduan Praktis Mengkaji Masalah dan Kebijakan Sosial: Bandung Alfabeta.

Erwan Agus Purwanto, Dyah Ratih Sulistyastuti. 2012. Implementasi Kebijakan Publik: Konsep dan Aplikasi di Indonesia. Yogyakarta: Gava Media.

Faried Ali, Andi Syamsu Alam, Sastro M.Wantu. 2012. Studi Analisis Kebijakan: Konsep, Teori dan
Aplikasi Sampel Teknik Analisa Kebijakan Pemerintah. Bandung: Refika Aditama.

Fred C. Lunenburg, Beverly J. Irby. 2006. The Principalship. America: Wadsworth.

Gusti Ketut Arya Sunu. 2014. Studi Kebijakan Nasional. Singa raja: Graha ilmu.

A.A.R.Tilaar, Riant Nugroho. 2008. Kebijakan Pendidikan. Yogyakarta: Pustaka Pelajar.

Hendarman. 2015. Revolusi Kinerja Kepala Sekolah. Jakarta: Indeks.

Imam Gunawan, Noor Benty. 2017.Manajemen Pendidikan. Bandung. Alfabeta.

Juklak Penyaluran Dana P IP Tahun 2017.

Juklak Penyaluran Dana PIP Tahun 2018.

Maswardi M.Amin. 2016. Manajemen Mutu. Yogyakarta: Media Akademi.

Mukhtar Widodo. 2000. Konstruksi ke Arah Penelitian Deskriptif. Yogyakarta: Ayyrrouz.

Nanang Fattah. 2013. Analisis Kebijakan Pendidikan. Bandung: PT Remaja Rosdakarya.

Riant Nugroho. 2008. Pendidikan yang Unggul. Yogyakarta: Pustaka Pelajar.

Riant Nugroho. 2015. Kebijakan Publik di Negara-Negara Berkembang. Yokyakarta: Pustaka pelajar.

Solihin Abdul Wahab. 2012. Analisis Kebijakan. Dari formulasi Kepenyusunan Model-model Implementasi Kebijakan Publik. Jakarta: Bumi Aksara.

Stephen P.Robbins, Timothy A.Judge. 2014. Essentials of Organizational Behavior. Pearson.

Sugiyono. 2017. Metode Penelitian Kebijakan. Bandung: Alfabeta.

Sugiyono. 2016. Metode Penelitian Pendidikan. Pendekatan Kualitatif, Kuantitatif dan R\&D: Bandung: Alfabeta.

Sugiyono. 2008. Metode Penelitian Kuantitatif Kualitatif dan $R \& D$. Bandung: Alfabeta.

Sugiyono. 2005. Memahami Penelitian Kualitatif. Bandung: Alfabeta.

Syafaruddin. 2008. Efektivitas Kebijakan Pendidikan Konsep Strategi, dan Aplikasi Kebijakan menuju Organisasi Sekolah Efektif. Jakarta: Rineka Cipta. 